YEARBOOK

of ANTITRUST

and REGULATORY

STUDIES

www.yars.wz.uw.edu.pl
Peer-reviewed scientific periodical, focusing on legal and economic issues of antitrust and regulation. Creative Commons Attribution-No Derivative Works 3.0 Poland License.

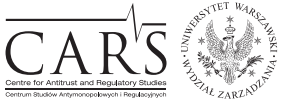

Centre for Antitrust and Regulatory Studies, University of Warsaw, Faculty of Management www.cars.wZ.uw.edu.pl

\title{
Problems Related to Determining of a Single Economic Entity under Competition Law
}

\author{
by \\ Raimundas Moisejevas and Danielius Urbonas*
}

\section{CONTENTS}

I. Introduction

II. The concept of a single economic entity

III. The meaning of 'control' under competition law

1. Group of companies and a single economic entity

2. The meaning of a 'control'

IV. The criteria for the determination whether de jure separate undertakings constitute a single economic entity

V. Presumption of decisive influence

VI. Conclusions

\section{Abstract}

The article explores the problems related to the determination of a single economic unit under competition law. The first part of the article addresses the concept of a single economic entity. It is presumed that companies belonging to a group are separate undertakings, but under certain circumstances the group might constitute a single economic entity. The second part refers to the analysis of the concept of 'control', which is the main criterion describing the relationship inside a group of companies. The third part refers to the analysis of the cases when de jure separate undertakings are recognized as a single economic entity. When a company exercises decisive influence over another company, they form a single economic

* Dr. Raimundas Moisejevas - Attorney at law, Arbitrator, ICSID Conciliator and Professor in Business Law Department, Faculty of Law, Mykolas Romeris University, Lithuania; raimundas.moisejevas@vilgerts.com; Danielius Urbonas - Attorney at law, Master of Laws at Mykolas Romeris University (Lithuania), danielius.urbonas@gmail.com. Article received: 9.08.2017; accepted: 30.09.2017. 
entity and, hence, are part of the same undertaking. Decisive influence is the most important criterion for recognizing that de jure separate undertakings constitute a single economic unit. Finally, the fourth part refers to problems concerning the presumption of the decisive influence. It is presumed that a parent company exercises a decisive influence over a subsidiary where it holds 100 percent of capital. Thus, separate companies are recognized as a single economic unit, if 100 percent of a company's capital is owned by the controlling entity.

\section{Resumé}

Larticle explore les problèmes liés à la détermination d'une entité économique unique en vertu du droit de la concurrence. La première partie de l'article aborde le concept d'une entité économique unique. Il est présumé que les sociétés appartenant à un groupe sont des entreprises distinctes, mais dans certaines circonstances, le groupe pourrait constituer une entité économique unique. La seconde partie se réfère à l'analyse du concept de «contrôle», qui est le critère principal décrivant la relation au sein d'un groupe de sociétés. La troisième partie se réfère à l'analyse des affaires où des entreprises distinctes de jure sont reconnues comme une entité économique unique. Enfin, la quatrième partie se réfère à des problèmes concernant la présomption de l'influence décisive. Il est présumé qu'une société mère exerce une influence décisive sur une filiale dans laquelle elle détient $100 \%$ du capital. Ainsi, des sociétés distinctes sont reconnues comme une seule unité économique si $100 \%$ du capital d'une société appartient à l'entité qui la contrôle.

Key words: competition law; concept of the control; decisive influence; one economic unit; parent company; single economic entity; subsidiary; undertaking.

JEL: K21

\section{Introduction}

The concept of a single economic entity is one of key topics of competition law. Every time when a competition authority intends to apply the provisions of competition law towards some entity, at first it is necessary to evaluate whether such entity constitutes an undertaking. For example, when the competition council starts investigation concerning an alleged bid-rigging agreement, it firstly should evaluate whether the entities, which are allegedly in breach of the competition law, are meeting the criteria of an undertaking. To be described as an undertaking, the entity must satisfy two criteria. First, an entity should perform economic activity. Second, it must be independent and autonomous. The concept of an undertaking encompasses every entity 
engaged in an economic activity, regardless of the legal status of the entity and the way in which it is financed ${ }^{1}$. Such approach towards an undertaking is described as functional (Odudu, 2004-2005, pp. 211-242), in that it focuses on the type of activity performed rather than on the characteristics of the actors which perform it $^{2}$.

While describing an entity as an undertaking, the economic criteria are more important than the legal status of the entity (Lasok, 2004, p. 383). The Law on Competition of the Republic of Lithuania provides that an undertaking shall mean an enterprise, or other legal or natural persons, which perform or may perform economic activities ${ }^{3}$. The concept of an undertaking is not identical with the question of legal personality for the purposes of company law or fiscal law. This term may refer to any entity engaged in commercial activities and to a parent or to a subsidiary or to the unit formed by the parent and subsidiaries together ${ }^{4}$.

The concept of an undertaking designates an economic unit (single economic entity) for the subject-matter of the agreement in question, even if in law the unit consists of several persons, natural or legal ${ }^{5}$. An undertaking is independent, if it is not influenced and controlled by another entity. Subsidiaries usually are not treated as separate undertakings in relation to the parent company. If a subsidiary has a separate legal personality but does not enjoy real autonomy in determining its course of action, the behavior of such subsidiary may be imputed to the parent company ${ }^{6}$. Therefore, an agreement to coordinate prices between the parent company and the subsidiary in most cases will not be treated as anticompetitive, since it is not concluded between

1 CJ judgment of 23.04.1991, Case C-41/90 Höfner and Elser v Macroton GmbH, ECLI:EU:C:1991:161, para. 21. Such definition is also found [in:] Whish, 2001.

2 Opinion of Advocate General Jacobs delivered on 22.05.2003, Joined Cases C-264/01, C-306/01, C-354/01 and C-355/01 AOK Bundesverband, Bundesverband der Betriebskrankenkassen (BKK), Bundesverband der Innungskrankenkassen, Bundesverband der landwirtschaftlichen Krankenkassen, Verband der Angestelltenkrankenkassen eV, Verband der Arbeiter-Ersatzkassen, Bundesknappschaft, See-Krankenkasse and Ichthyol-Gesellschaft Cordes, Hermani \& Co., Mundipharma GmbH (C-306/01), Gödecke GmbH (C-354/01), Intersan, Institut für pharmazeutische und klinische Forschung GmbH (C-355/01), ECLI:EU:C:2003:304, para. 25.

3 Law on Competition of the Republic of Lithuania, Official Gazette (1999. No. VIII-1099).

4 Commission Decision of 23.04.1986, IV/31.149 - Polypropylene (OJ L 230, 18.8.1986, p. 1), para. 99.

5 CFI judgment of 15.09.2005, Case T-325/01, DaimlerChrysler AG v Commission ECLI:EU:T:2005:322, para. 85; ECJ judgment of 12.07.1984, Case 170/83 Hydrotherm, ECLI:EU:C:1984:271, para. 11; GC judgment of 3.03.2011, Joined cases T-325/01 and T-234/95 DSG v Commission, ECLI:EU:T:2011:69, para. 124; CJ judgment of 14.12.2006, Case C-217/05, Confederación Española de Empresarios de Estaciones de Servicio, ECLI:EU:C:2006:784, para. 40.

${ }^{6}$ ECJ judgment of 14.07.1972, Case C-48/69, Imperial Chemical Industries v Commission, ECLI:EU:C:1972:70, para. 133. 
two independent undertakings. The parent and subsidiary companies are often treated as a single economic entity under the competition law. We may conclude that determination of a single economic entity has a huge practical importance in disputes with the Competition Council.

The court practice in Lithuania is not clear enough on the application of the criteria concerning determination of a single economic entity. In most disputes with the Competition Council when the parties aimed to prove that separate entities constitute a single economic entity, they failed to do so. One of the reasons is a lack of a clear-cut theoretical and practical approach towards proving of a single economic entity under the Lithuanian competition law. We hope that this article will help understand better the criteria under which related companies might be recognized as a single economic unit.

The aim of this article is to identify the key principles used for the establishment whether separate entities constitute a single economic entity.

\section{The concept of a single economic entity}

It is presumed that companies belonging to a group are separate undertakings (Ferran, 1999, p. 31). However, under certain circumstances a group of companies may constitute a single economic entity according to competition law. If one undertaking de jure or de facto exercises decisive influence over another company's commercial policy, such separate companies are not competitors since competing companies usually are not pursuing a common goal. The main criteria for determining whether the undertakings form a single economic entity is the ability of the subsidiary (a controlled entity) to determine its course of action in the market ${ }^{7}$. Different companies belonging to the same group who do not determine independently their own conduct on the market might be recognized as one undertaking within the meaning of Article 101 TFEU and 102 TFEU $^{8}$. For the purpose of applying the competition rules, formal separation of two companies resulting from their having distinct legal identity is not decisive. The test is whether there is unity in their conduct on the market. ${ }^{9}$ Therefore, when the controlling entity

7 Case C-48/69, Imperial Chemical Industries, para. 134.

8 CFI judgment of 30.09.2003, Case T-203/01 Michelin v Commission, ECLI:EU:T:2003:250, para. 290; CJ judgment of 10.09.2009, Case C-97/08 P Akzo Nobel NV v Commission, ECLI:EU:C:2009:536, para. 58.

9 CFI judgment of 11 December 2003, Case T-66/99 Minoan Lines SA v Commission, ECLI:EU:T:2003:337, para. 123; 24.10.1996, CJ judgment, Case C-73/95 P Viho Europe BV v Commission, ECLI:EU:C:1996:405. 
can influence pricing policy, production activities, sales objectives, cash flow, stocks and marketing of the other company, it is usually concluded that these companies are closely related and constitute a single economic entity ${ }^{10}$.

However, the EU competition law does not provide an unequivocal definition of the term 'single economic entity'. This means that when dealing with some practical cases, attorneys need to engage in a thorough discussion with competition authorities on whether a group of companies should be treated as a single economic entity. According to Nada Ina Pauer (2014) the concept 'single economic entity' had been established to characterize the level of integration allowing for a distinguished treatment of corporate groups. The concept might be described as a blanket term, derived from other areas of law (tax law), which was modified by the Court of Justice for the purposes of competition law. This way the EU institutions developed a common concept for the treatment of corporate groups under competition law.

The single economic entity doctrine was developed in the jurisprudence of the Court, when the Court paid attention to the main criteria for determination of the breach of Article 101 TFEU. The first criterion - the existence of an agreement or concerted practice. Second criterion - distortion of competition in the respective market. Through the doctrine of a 'single economic entity', an agreement (or concerted practices) between the parent company and subsidiary (when the subsidiary cannot independently determine its course of action) should be viewed as an exception from the prohibition of Article 101 (Ward, 1985, p. 377). The agreement concluded between the parent and subsidiary usually refers to the internal distribution of tasks and not to an agreement between independent competing undertakings.

The decision of the European Commission in the Christiani and Nielsen case $^{11}$ is regarded as the first one in the development of the 'single economic entity doctrine' in EU competition law (Pauer, 2014). The Commission held that an agreement concerning the division of the market concluded between the parent and subsidiary companies should be viewed as allocation of work inside the undertaking ${ }^{12}$. The Commission recognized that the agreement on the division of the market concluded between the parent and its 100-percent controlled subsidiary is legal. It was found that the respective companies are not competitors and hence competition between them cannot be distorted ${ }^{13}$.

\footnotetext{
10 Case C-97/08 P Akzo Nobel NV, para. 58-59.

11 Commission Decision of 18.6.1969, IV/22.548, Christiani and Nielsen (OJ L 165, 5.7.1969, p. 12).

12 Ibidem.

13 The European Commission further developed doctrine in Kodak case (Commission Decision of 30.6.1970, 70/332/CEE, Kodak (OJ L 147, 7.7.1970, p. 24), by claiming that the instructions, which parent company provides to subsidiaries are different from the concept
} 
The Commission in Ernst \& Young France/Andersen France case recognized that five de jure separate legal entities that are part of Ernst \& Young international network constitute a single economic unit ${ }^{14}$. There was no central distribution of revenues between the individual member firms, but strong common financial interest was established by the systematic referral of clients across the network. In the Ernst \& Young structure, a clear permanent economic centralized management was established, supplemented by centrally formulated policies and centrally provided services. The member firms rely on the common brand name and its reputation, the worldwide network and the centrally developed and monitored professional standards and common client relationships. These links are reinforced by the central co-ordination and facilitation of standards, strategies and initiatives and the provision of common services. These elements indicate a decisive degree of common economic management and common financial interest. This led to the conclusion that Ernst \& Young is a single economic entity ${ }^{15}$. In this decision, the Commission recognized de jure separate legal entities as a single economic unit based on different features and analyzed factual relationships between entities forming the international network. However, in practical cases it is very difficult to evaluate whether de jure separate legal entities are so closely related to be recognized as a single economic entity. For example, in one of the disputes with the competition council, decisions of shareholders and boards of two companies were presented to prove that a certain shareholder had controlling stakes in both companies.

Bearing in mind that the competition law has developed from the US legal practice (Moisejevas, 2007, p. 63), we should also pay attention to the US court decisions relating to the 'single economic entity'. The Supreme Court of the United States in Cooperweld Corp. v Independence Tube Corp.

of the 'agreement' under competition law. At the same time the Commission decided that competition is possible between the undertakings belonging to the group of the companies. In Beguelin Import co v S.A.G.L Import Export the Court for the first time had an opportunity to comment on the agreements concluded inside the group of the companies. The Court held that although a subsidiary has separate legal personality, it still enjoys no economic independence (ECJ judgment of 25.11.1971, Case 22/71, Beguelin Import co. v S.A.G.L Import Export, ECLI:EU:C:1971:113, para. 8). Further on the Court has been developing the doctrine of a single economic entity in several the other cases (ECJ judgments of: 31.10.1974, Case 15/74, Centrafarm B.V. \& Adriaan De Peijper v Sterling Drug Inc, ECLI:EU:C:1974:114; 31.10.1974, Case 16/74, Centrafarm BV \& Adriaan De Peijper v Winthrop BV., ECLI:EU:C:1974:115; 12.07.1984, Case 170/83, Hydrotherm v Compact, ECLI:EU:C:1984:271; 4.04.1988, Case 30/87, Corinne Bodson v SA Pompes funebres des regions liberees, ECLI:EU:C:1988:225; CJ judgment of 23.04.1991, Case C-41/90, Hofner and Elser v Macroton, ECLI:EU:C:1991:161; CFI judgment of 10.03.1991, Case T-11/89, Shell v Commission, ECLI:EU:T:1992:33).

14 Commission Decision of 5.09.2002, COMP/M.2816 Ernst \& Young France/Andersen France.

15 COMP/M.2816 Ernst \& Young France, para. 17. 
raised the question of why does the competition law prohibit undertakings from coordination of their actions in the market ${ }^{16}$. The US Supreme Court answered that after the conclusion of an anticompetitive agreement the market loses independent decision-making centers, which should be protected by the competition law. In case of conspiracy, a couple of entities that previously pursued their interests separately are acting as one for their common benefit. This only reduces the diverse directions in which economic power is aimed and increases the economic power moving in one direction ${ }^{17}$. The Court held that an internal 'agreement' concluded within a group of companies to implement single, unitary policies does not raise antitrust dangers. Such conclusion is based on several arguments: 1) Employees of a single economic entity do not pursue separate economic interests, so agreements among them do not suddenly bring together economic power that was previously pursuing divergent goals; 2) Actions within a single economic entity might be coordinated to compete effectively in the market; 3) Cooperation within a group might be necessary to compete effectively with competing entities ${ }^{18}$.

The US Supreme Court claimed that the agreements between a subsidiary and its parent company were not prohibited under competition law, since they are pursuing common interests. Their general corporate actions are guided or determined not by separate corporate consciousness, but one ${ }^{19}$. A group of companies is like a multiple team of horses drawing a vehicle under the control of a single driver. Even without a formal agreement, the subsidiary acts for the benefit of the parent, its sole shareholder. If a parent agrees with its subsidiary to pursue a course of action, there is no sudden joining of economic resources that had previously served different interests ${ }^{20}$. We could enjoy the way the US Supreme court structures arguments and provides clear and reasonable explanation of the concept.

It is clear that the reasoning of the CJEU and the US Supreme Court concerning the single economic entity doctrine coincides. Courts from the EU and the US are using the same criteria for a recognition of a single economic entity. It is recognized that the agreement between the subsidiary and parent company should be treated as an internal agreement and not distorting competition.

16 Decision of the Supreme Court of the United States of 19.06.1984, Cooperweld Corp. $V$. Independence Tube Corp. 467 U.S. 752 (1984).

17 Ibidem, para. 768-769.

18 Ibidem.

19 Ibidem, para. 771.

20 Ibidem, para. 771. The US Supreme Court took another important decision in American Needle, Inc. v National Football League case developing single economic entity doctrine. Decision of the Supreme Court of the United States of 24.05.2010, American Needle, Inc. v National Football League, Case No. 130 S.Ct.2201. 


\section{The meaning of 'control' under competition law}

\section{Group of companies and a single economic entity}

We have referred many times to the term 'group of companies' while discussing the 'single economic entity' concept. Although these concepts are quite similar, they also should be clearly separated. A group of companies not necessarily constitutes a single economic entity. EU competition law does not provide a clear-cut definition of a group of companies. For clarification, we might refer to the Merger Regulation ${ }^{21}$. The Merger Regulation does not delineate the concept of a group in a single abstract definition, but sets out in Article 5(4)(b) certain rights or powers. If an undertaking concerned directly or indirectly has such links with other companies, those are to be regarded as a part of its group for purposes of turnover calculation under the Merger Regulation $^{22}$. An undertaking which has in another undertaking the rights and powers mentioned in Article (5)(4)(b), it will be referred to as the 'parent' of the latter, whereas the latter is referred to as a 'subsidiary' of the former. The concept of a group of companies provided in Article 5(4)(b) is based on the existence of a formal control (Broberg, 2006, p. 68).

In accordance with Article 5(4)(b) of the Merger Regulation, such control exists when: the undertaking concerned owns more than half of the capital or business assets of other undertakings, has more than half of the voting rights, has legally the power to appoint more than half of the board members in other undertakings, or has the right to manage the undertaking's affairs.

The Lithuanian Law on Competition established the concept of a 'group of associated undertakings' to identify which undertakings, due to their mutual control or interdependence and possible concerted actions, are considered as one undertaking when calculating joint income and market share. Article 3(14) of the Lithuanian Law on Competition provides several criteria which should be established to presume the existence of a group of associated undertakings. The criteria under the Lithuanian Law on Competition ${ }^{23}$ are similar to the requirements of the Merger Regulation.

${ }^{21}$ Council Regulation (EC) No. 139/2004 of 20.01.2004 on the control of concentrations between undertakings (the EC Merger Regulation) (OJ L 24, 29.01.2004, p. 1).

22 Commission Consolidated Jurisdictional Notice under Council Regulation (EC) No 139/2004 on the control of concentrations between undertakings, 2008/C 95/01 (OJ C 95, 16.4.2008, p. 1), para. 176.

${ }^{23}$ Law on Competition of the Republic of Lithuania, Official Gazette, 1999. No. VIII-1099. 
The existence of a formal control does not necessarily mean that the controlling undertaking might exercise such decisive influence, which would deprive the controlled undertaking from the freedom to determine its course of action in the market. The Court of Justice held in Corinne Bodson v SA Pompes funèbres des régions libérées that the fact that holders of concessions belong to the same group of undertakings is not decisive for evaluating whether the undertakings form an economic unit. ${ }^{24}$ Account must be taken of the nature of the relationship between the undertakings belonging to that group. We may conclude that to establish the existence of a group of companies, it is sufficient to establish the existence of formal control. However, the existence of a formal de jure control is not sufficient for the identification of a single economic entity. This means that in a practical situation we must analyze the details related to the nature of the control.

\section{The meaning of a 'control'}

Although we came to the conclusion that the term 'group of companies' is different from 'single economic entity', both terms describe a specific relationship between de jure separate undertakings. Therefore, while disclosing the features of a single economic entity, we may refer to the criteria used for defining a group of companies. The main criterion which describes the relationship inside a group of companies is 'control' (Kirilevičiūte, 2012, p. 99; Banevičienè, 2009, pp. 65-73). For example, UNCITRAL 'Legislative guide on Insolvency Law' describes an enterprise group as two or more enterprises that are interconnected by control or significant ownership. ${ }^{25}$ At this point we should note that control might have positive and negative meanings. In a positive sense, control is understood as an opportunity to make decisions concerning operational issues of the undertaking. In the negative sense, control is understood as an opportunity to block adoption of appropriate decisions. There might also be sole and collective types of control. For example, collective control may take place when parties conclude a shareholders agreement, which foresees the joint use of voting rights or entitles to control the undertaking through other means. There are cases when control is indirect. For example, an investment company might gain indirect control of the undertaking in case the undertaking is financed by a fund managed by the investment company. Every situation with indirect control should be evaluated based on existing

24 Case C-30/87, Corinne Bodson.

25 UNCITRAL (2012). Legislative guide on Insolvency Law. Part three: Treatment of enterprise groups in insolvency, 2. 
circumstances. It should be emphasized that acquisition of control might be recognized even if the undertakings claim they did not seek to gain control ${ }^{26}$.

De jure and de facto control are distinguished. Generally, de jure control exists in case the controlling undertaking directly or indirectly owns more than 50 percent of the shares of the controlled undertaking. At the same time the existence of a specific number of shares does not necessarily mean that the party shall have the same number of votes. De facto control is more problematic, since it may take different shapes. It is not necessary to conclude any type of formal agreement for de facto control to appear. Such control should be evaluated through an analysis of decisions relating to the management of the company, structural links, existing agreements, loans, common interests of shareholders and other conditions. For example, a main shareholder may depend on a minority shareholder, if this minority shareholder has the necessary know-how and the main shareholder acts only as an investor. There is no exhaustive list how de facto control may reveal itself.

Article 3(2) of the Merger Regulation defines control as the rights, contracts or any other means which confer the possibility of exercising decisive influence on an undertaking, by ownership or the right to use all or part of the assets of an undertaking, as well as rights or contracts which confer decisive influence on the composition, voting or decisions of the organs of an undertaking. Article 3(8) of the Lithuanian Law on Competition describes control as any rights which entitle a person to exert a decisive influence on the activity of an undertaking, including the right of ownership to all of part of the assets of the undertaking, as well as other rights which permit exertion of a decisive influence on the decisions of the bodies of the undertaking or the composition of its personnel (Butkevičius and Civilka, 2012, p. 9). Such control is described as certain rights, agreements or other means, which together or separately enable the exercising of a decisive influence over the undertaking, irrespectively whether such rights are gained based on the ownership of shares, voting or other agreements on the management of the undertaking or any other way (Goyder, 2003, p. 347).

We may conclude that an undertaking exercising de jure control is not necessarily empowered to exercise such level of influence that might restrict freedom of the controlled undertaking to determine its behavior in the market. The influence should carry a certain 'weight' (Broberg, 2004, p. 742). Such influence in the competition law is referred to as 'decisive influence'27. In a practical case, it is quite difficult to determine whether the exact influence

${ }^{26}$ Commission Decision of 5.10.1992, Case No IV/M.157 - Air France/Sabena (Non-opposition to a notified concentration) (OJ C 272, 21.10.1992, p. 5).

27 Article 3(10) of the Law on Competition of the Republic of Lithuania provides that decisive influence means the situation when the controlling undertaking implements or can 
should be viewed as 'decisive', since it depends on quite a big number of criteria. Even after a detailed evaluation of influence is conducted, it may still be not completely clear.

The Commission held in the Arjomari/Wiggins Teape case that $39 \%$ percent of shares were sufficient for the exercise of sole control ${ }^{28}$. It was decided that Arjomari would be able to exercise decisive influence on WTA because the remainder of WTA's shares were held by about 107,000 other shareholders, none of whom owns more than $4 \%$ and with only three shareholders having over 3\% of the issued share capital. After an analysis of decisions of the Commission and the Article 3(2) of the Merger Regulation it becomes clear that 'decisive influence' means less than legal control. The Merger Regulation aims to regulate mergers of independent companies which do not change their respective status to 'parent' and 'subsidiary' (Banevičienè, 2009). It also follows that it is not necessary for the controlling undertaking to acquire 'legal control' to exercise decisive influence over the controlled undertaking. It might be possible to have much less than 50 percent of the shares to exercise decisive influence ${ }^{29}$.

\section{The criteria for the determination whether de jure separate undertakings constitute a single economic entity}

The Communication - Guidelines on the applicability of Article 101 of the Treaty on the Functioning of the European Union to horizontal co-operation agreements provides that companies which form part of the same 'undertaking' within the meaning of Article 101(1) are not considered to be competitors for the purposes of these guidelines. When a company exercises decisive influence over another company, they form a single economic entity and, hence, are part

implement his decisions in relation to the economic activity of the controlled undertaking, the decisions of its bodies or the composition of its personnel.

${ }^{28}$ Commission Decision of 10.12.1990, IV/M25 Arjomari/Wiggins Teape (OJ C 321, 21.12.1990, p. 1).

${ }^{29}$ In Renault / Volvo merger the Commission established that in relation to the markets of the trucks and busses Renault and Volvo acquired respectively $45 \%$ of the shareholdings of the other party and these share acquisitions were substantial interests resulting in an almost equal sharing of losses and profits. Moreover, the economic interests involved created a strong situation of common interests which, together with the other factors mentioned hereafter, lead to a de facto permanent common control situation and thus established a single economic entity between the two parties - Commission Decision of 7.11.1990 declaring a concentration to be compatible with the common market (Case No IV/M.0004 - RENAULT / VOLVO) according to Council Regulation (EEC) No 4064/89 (OJ C 281, 9.11.1990, p. 2). 
of the same undertaking. The same is true for sister companies, over which decisive influence is exercised by the same parent company. They are not considered to be competitors even if they are both active in the same relevant markets ${ }^{30}$. Therefore, decisive influence is the most important criterion for recognizing that de jure separate undertakings constitute a single economic unit. In case of decisive influence, the controlled undertaking is not able to freely determine its economic behavior. On the other hand, it is difficult to establish decisive influence because of many different forms it may take.

Bearing in mind some contradictions that relate to the establishment of a single entity, it does not come by surprise that some scholars and officials believe there should be more legal clarity in the field. The Commission Regulation 1407/2013 on the application of Articles 107 and 108 of the Treaty on the Functioning of the European Union to de minimis aid provides that for the sake of legal certainty and reduction of the administrative burden, it should provide a list of criteria for determining when two or more enterprises are to be considered single undertaking ${ }^{31}$. The present Regulation provides that a 'single undertaking' includes all enterprises having at least one of the following relationships with each other: a) one enterprise has a majority of the shareholders' or members' voting rights in another enterprise; (b) one enterprise has the right to appoint or remove a majority of the members of the administrative, management or supervisory body of another enterprise; (c) one enterprise has the right to exercise a dominant influence over another enterprise pursuant to a contract entered into with that enterprise or to a provision in its memorandum or articles of association; (d) one enterprise, which is a shareholder in or member of another enterprise, controls alone, pursuant to an agreement with other shareholders in or members of that enterprise, a majority of shareholders' or members' voting rights in that enterprise ${ }^{32}$.

In our opinion, the above-mentioned criteria might be used universally for the determination of a 'single undertaking'.

In real court disputes it is very difficult to establish whether a group of companies constitutes a 'single undertaking'. Moreover, sometimes companies investigated by the competition authorities in cartel cases try to justify their behavior based on the 'single undertaking' concept. While determining whether

${ }^{30}$ Communication from the Commission - Guidelines on the applicability of Article 101 of the Treaty on the Functioning of the European Union to horizontal co-operation agreements (OJ 2011 C 11, 14.1.2011, p. 1), para. 11.

31 Commission Regulation (EU) No 1407/2013 of 18.12.2013 on the application of Articles 107 and 108 of the Treaty on the Functioning of the European Union to de minimis aid (OJ L L 352, 24.12.2013, p. 1).

32 Article 2(2) Regulation 1407/2013. 
a group of companies amount to a 'single undertaking' it is necessary to pay attention to several factors (Goyder, 2003, p. 347; Švirinas, 2004, p. 27). It is important to evaluate all the evidence related to organizational, economic and legal ties between the undertakings, which may differ in specific cases ${ }^{33}$. Defining 'decisive influence' constitutes a big problem in many cases, since real control and 'decisive influence' may occur in many ways (Goyder, 2003, p. 347).

The European Commission established the existence of control in the Anglo American Corporation/Lonrho case $^{34}$ on the basis that the Anglo American Corporation acquired 27 percent in Lonrho. The disparity of the other shareholders meant that AAC could gain de facto control over Lonrho. The Commission reviewed polls held at Lonrho shareholders' meetings in previous years to ascertain whether the Anglo American Corporation level of holding would suffice to establish control, thus classifying the operation as a concentration (Ezrachi and Gilo, 2006, pp. 327-349). Usually the share of voting rights held by the shareholders is not the only criterion. Even without special voting and veto rights, collective choice problems could produce a decisive influence with even smaller amount of shareholding than in the Anglo American Corporation/Lonrho case (Easterbrook and Fischel, 1991). Moreover, it may even be important how the undertakings treat themselves while evaluating the existence of a single economic entity. The Competition Council of Lithuania has also analyzed the above-mentioned criteria ${ }^{35}$. The Competition Council analyzed correspondence between undertakings, publicly available information concerning a particular group of companies and other circumstances. The Competition Council concluded that the actions of the companies show that they view themselves as a single economic entity aiming to achieve common goals.

An undertaking will be treated as having a decisive influence in relation to the other undertaking even if, while having the ability to exercise decisive influence, it will not exercise its power. The European Commission established in the McCormic/CPC Rabobank/Osmann case that the participation of all the shareholders is necessary to pass decisions concerning management of the joint company or commercial policy ${ }^{36}$. The low capital share of a shareholder and the agreement on a fixed return could not rebut the fact that the shareholder had the legal right to exert a decisive influence on the joint venture. The

33 Case C-97/08 P Akzo Nobel NV.

34 Commission Decision of 23.04.1997, 98/335/EC, declaring a concentration to be compatible with the common market and the functioning of the EEA Agreement (IV/M.754 - Anglo American Corporation/Lonrho).

35 Decision No. 2S-16 of the Competition Council of the Republic of Lithuania of 10.07.2008.

36 Commission Decision of 29.10.1993, IV/M.330 - McCormick/CPC/Rabobank/Ostmann, para. 17. 
mere possibility of exercising a decisive influence was sufficient, unless clearly undermined by factual evidence.

As the world economy becomes global, quite often we must deal with international groups of companies. To determine whether an undertaking that belongs to the international group is empowered to influence another undertaking, we may need to analyze different national laws. National laws establish rules for passing economically important decisions, the composition of the management, competence of the board and supervisory organs, as well as other key elements. National laws determine the real legal and economic impact of the rights acquired on the contractual and similar basis. For example, minority shareholders have more rights in certain jurisdictions and this is very important for the existence of decisive influence. National legal acts also might provide that certain entities, for example trade unions, may have a certain level of control in relation to the undertaking, although they are neither managers, nor shareholders in the company. The structure of a group of companies, the existing hierarchy between undertakings, influence of the representatives of one undertaking on the management of another, exchange of information inside the group are also significant factors.

According to the Court of Justice, even if undertakings are closely related and may be viewed as associated, it does not follow that one of them has a decisive influence towards another and that a 'single economic entity' might be established. The Supreme Administrative Court of the Republic of Lithuania also provides that the existence of common shareholders and employees does not allow to claim that such undertakings should not be viewed as competitors ${ }^{37}$. Sometimes even a majority shareholding will not ensure the ability to exercise decisive influence in relation to the controlled undertaking. Usually the most important is not the amount of the shares, but the number of votes that allows influencing an undertakings' business strategy and decisions of the management. Moreover, the rights granted to the minority shareholders under national law are not sufficient for the recognition of decisive influence (Hawk and Huser, 1993). In order to establish the decisive influence the main attention should be given to the business strategy of the undertakings and de facto actions. The mere fact that the share capital of two separate undertakings belongs to the same person or family, is not sufficient to recognize that those undertakings constitute an economic unit ${ }^{38}$.

37 Decision of the Supreme administrative court of the Republic of Lithuania of 21.07.2011, No. A502-2256/2011, UAB „Prof-T“ $v$ Competition Council; decision of the Supreme Administrative Court of the Republic of Lithuania of 21.06.2012, No. A552-2016/2012, UAB „Specialus montažas-NTP“v Competition Council.

38 CJ judgment of 2.10.2003, Case C-196/99 P, Siderúrgica Aristrain Madrid SL v Commission, ECLI:EU:C:2003:529, para. 99. 
Scholars of competition law provide a non-exhaustive list of the criteria for the determination of the decisive influence of the controlling undertaking: ability to appoint/dismiss management, board members; influence of changes in the shareholding; influence of the dividend policy; influence on business plans; influence of investments policy; influence on financial planning; influence on production. As mentioned, the list is non-exhaustive and every situation should be evaluated separately (Banevičienè, 2009, p. 56-66; Pauer, 2014). Therefore, it is almost impossible to formulate universal rules for the determination of the existence of a single economic entity. However, there are certain exceptions, when the demonstration of decisive influence is not so complicated. In some cases, decisive influence is presumed. In the following section, we will analyze the presumption of decisive influence.

\section{Presumption of decisive influence}

In some cases, existence of decisive influence is determined in accordance with the presumptions established in the practice of the Court of Justice. It is presumed that a parent company exercises a decisive influence over a subsidiary where it holds 100 percent of the capital ${ }^{39}$. Therefore, separate companies are automatically recognized as a single economic unit, if 100 percent of the capital of a company is owned by the controlling entity. The presumption of liability deriving from the ownership of capital applies not only in cases where there is a direct relationship between the parent company and its subsidiary, but also in cases where that relationship is indirect, by way of an interposed subsidiary. It follows that in the specific case where a holding company holds 100 percent of the capital of an interposed company which, in turn, holds the entire capital of a subsidiary of its group which has committed an infringement of EU competition law, there is a rebuttable presumption that that holding company exercises decisive influence over the conduct of the interposed company and indirectly, via that company, over the conduct of that subsidiary ${ }^{40}$.

The presumption of the decisive influence is based on the apparent fact that when the parent company is the only shareholder of the subsidiary, it has all the necessary measures to fully determine behavior of the subsidiary. Moreover, when the parent company is the sole shareholder in the subsidiary, it has at its disposal every possible means of ensuring that the subsidiary's

\footnotetext{
39 Case C-97/08 P Akzo Nobel NV, para. 39.

40 CJ judgment of 20.01.2011, Case C-90/09, General Quimica SA v Commission, ECLI:EU:C:2011:21, para. 86-88.
} 
commercial conduct is aligned with its own. A single shareholder defines the degree of autonomy of the controlled undertaking through adoption of the Articles of Association, the appointment of management, approval of strategic commercial decisions and so on. The economic unity between the parent company and its subsidiary is further protected by obligations arising under the company law of the Member States, such as the obligation to keep consolidated accounts, the obligation for the subsidiary to account periodically for its activities to the parent company and also by the approval of the subsidiary's accounts in a general meeting, consisting solely of the parent company, which necessarily means that the parent company follows, at least in broad terms, the commercial activities of the subsidiary. Therefore, the ownership of all or virtually all the capital of the subsidiary by a sole parent company means in principle that they pursue the same conduct on the market ${ }^{41}$. Moreover, the $\mathrm{CJ}$ held that if the parent company becomes a technical and financial coordinator or provides the subsidiary with financial and investment assistance, it may be sufficient to recognize that such a group of companies constitutes a single economic unit ${ }^{42}$.

Although it is difficult to imagine how the parent company might be separated from the subsidiary, the presumption of decisive influence might be rebutted by evidence demonstrating the independence of the subsidiary ${ }^{43}$. In such a case, it is for the parent company to put before the Court any evidence relating to the organizational, economic and legal links between its subsidiary and itself, which are apt to demonstrate that they do not constitute a single economic entity ${ }^{44}$.

Bearing in mind that the presumption of decisive influence might be denied when sufficient evidence concerning the independence of a subsidiary is provided, this presumption is treated as rebuttable (Kuzniecowa, 2004, p. 27-28). At the same time the practice of the CJEU does not provide any clear criteria concerning separation of actions of the parent and subsidiary. Therefore, the CJEU formulated a strong presumption but failed to provide clear criteria for its rebuttal. In our opinion to achieve legal certainty, practice should be developed in order to formulate clear criteria for a rebuttal of the presumption. Although there exists a formal chance of a parent company to separate itself from the subsidiary, such possibility is quite theoretical. From the practical point of view, it is quite hard to imagine a parent company which

${ }^{41}$ CFI judgment of 11.07.2014, Case T-543/08, RWE AG / RWE Dea AG v Commission, ECLI:EU:T:2014:627, para. $42-43$.

${ }^{42}$ CJ judgment of 8.05.2013, Case C-508/11, Eni SpA v Commission, ECLI:EU:C:2013:289, para. 64-65.

43 Case C-97/08 P Akzo Nobel NV, para. 60-61.

44 Ibidem, para. 65. 
is not participating in the coordination of the group. As mentioned, according to the practice of the CJEU, any involvement of the parent company in an activity of a subsidiary potentially is sufficient for ascertaining the existence of decisive influence.

In Eni SpA v. Commission, the Commission held that in order to rebut the presumption based on the $100 \%$ ownership of the subsidiaries, Eni ought to have demonstrated that its subsidiary was managed as a separate undertaking for legal or regulatory reasons, or even that the $100 \%$ ownership was merely temporary and transitory, in order thus to demonstrate that it and its subsidiary did not form a single undertaking which committed the infringement in question ${ }^{45}$. We believe that the Commission has not provided a final list of the circumstances that should be proven.

We conclude that in case when one undertaking owns 'almost all' share capital of the controlled undertaking, the same presumption is applicable. The Court of Justice has held that the parent company that owns almost all share capital of the subsidiary is analogous to the situation of a single shareholder as much as it relates to the ability to exercise decisive influence over the subsidiary. Therefore, in such a case, there is a basis to apply the same rules of evidence and rely on the presumption that the parent company has exercised a decisive influence in relation to the subsidiary. In case this presumption is not rebutted, a conclusion should be made that the parent and subsidiary constitute a single economic unit. On the other hand, the rebuttal is more simple to exercise when the parent does not own 100 percent of the subsidiary.

\section{Conclusions}

We may conclude that several conditions should be established to decide that a group of companies constitutes a single economic entity. The main criteria is the ability of the subsidiary to determine its course of action in the market. The formal separation of two companies resulting from their having distinct legal identity is not decisive. The test is whether there is a unity in their conduct on the market.

If one undertaking de jure or de facto exercises decisive influence over another company's commercial policy, such separate companies should be recognized as a single economic entity and not as competitors, since competing companies usually do not pursue a common goal. Moreover, 'control' is the main criterion for the evaluation of the relationship inside a group of

45 Case C-508/11, Eni SpA, para. 59. 
companies. In this situation, the interested parties or the court should use the concepts of 'control' and 'decisive influence' like the concepts used in the legal acts on concentration control.

When a company exercises decisive influence over another company they form a single economic entity. Decisive influence is the key element for recognizing that de jure separate undertakings constitute a single economic unit. In case of decisive influence, a controlled undertaking is not able to freely determine its economic behavior. On the other hand, the competition authority and the court faces difficulties establishing decisive influence because of many different forms it may take. There is a non-exhaustive list of the criteria for the determination of the decisive influence of the controlling undertaking: the ability to appoint/dismiss management, board members; influence of changes in the shareholding; influence of the dividend policy; influence on business plans; influence of investment policy; influence on financial planning; influence on production. The competition authority also considers the practical aspects of the exercise of decisive influence. The chances to prove that companies constitute a single economic entity increases when a group of companies for example provides protocols of meetings and voting of the shareholders, approval of the business plans and so on. Providing of evidence concerning practical influence is especially important if the dominant shareholder has only around 50 percent of the shares in the subsidiary.

At the same time, we need to make a reservation that unfortunately it is almost impossible to formulate universal rules for the determination of the existence of a single economic entity, which could be applied in all cases. Several issues are still to be determined on a case-by-case basis. On the other hand, there are certain limited exceptions, when the decisive influence is presumed. A decisive influence is presumed and the existence of a single economic entity automatically follows when a parent company holds 100 percent of the capital in a subsidiary.

\section{Literature}

Banevičienè, A. (2009). Nehorizontaliu koncentraciju teisinis reguliavimas pagal Europos Bendrijos ir Lietuvos Respublikos konkurencijos teisę. Vilnius: Mykolo Romerio universitetas.

Broberg, M.P. (2004). The Concept of Control in the Merger Control Regulation. ECLR, 29(12), 741-751.

Broberg, M.P. (2006). The European Commission's Jurisdiction to Scrutinize Mergers. Tilburg Law Review, 11(2), https://doi.org/10.1163/221125903x00528 
Butkevičius, L. and Civilka, M. (2012). Komercinès paskirties nekilnojamojo turto nuomos sandoriai Lietuvos koncentracijų kontrolès sistemoje. Teisés problemos, 2(76).

Easterbrook, F.H. and Fischel, D.R. (1991). The Economic Structure of Corporate Law. Harvard University Press.

Ezrachi, A. and Gilo, D. (2006). EC Competition Law and the Regulation of Passive Investments Among Competitors. Oxford Journal of Legal Studies, 26(2), 327-349, https://doi.org/10.1093/ojls/gq1006

Ferran, E. (1999). Company Law and Corporate Finance. Oxford University Press: Oxford. Goyder, D.G. (2003). EC Competition Law, Oxford University Press: Oxford.

Hawk, B.E. and Huser, H.L. (1993). Controlling the Shifting Sands: Minority Shareholdings Under EEC Competition Law. Fordham International Law Journal, 17(2).

Kirilevičiūtè, L. (2012). Jurisdikcijos taisyklès pagal $2000 \mathrm{~m}$. gegužès 29 d. Tarybos reglamenta (EB) 1346/2000 dèl bankroto bylu. Vilnius: Vilniaus universitetas.

Kuzniecowa, O.A. (2004). Prezumcii w grazdanskom prawe. Juridicieskicj Centr-Press: Sankt Petersburg.

Lasok, KPE (2004). When Is an Undertaking Not an Undertaking. ECLR 25(7).

Moisejevas, R. (2007). Piktnaudžiavimas dominuojančia padėtimi: grobuoniška kainodara - esminiai požymiai. Jurisprudencija, 9(99).

Odudu, O. (2004-2005). The meaning of undertaking within 81 EC. The Cambridge Yearbook of European Legal Studies. 7.

Pauer, N.I. (2014). The Single Economic Entity Doctrine and Corporate Group Responsibility in European Antitrust Law. Kluwer Law International.

Švirinas, D. (2004). Vertikaliuju susitarimu reglamentavimas konkurencijos teisejje (Regulation of vertical agreements under competition law). Mykolo Romerio universitetas: Vilnius.

Ward, S.M. (1985). The Economic Unity Doctrine in the EEC: A Limited Exemption to Article 85 of the Treaty of Rome. Fordham International Law Journal, 9(2).

Whish, R. (2001). Competition Law, Butterworths: London. 